\title{
REVIEW
}

\section{Will pharmacogenetics allow better prediction of methotrexate toxicity and efficacy in patients with rheumatoid arthritis?}

\author{
P Ranganathan, S Eisen, W M Yokoyama, H L McLeod
}

Methotrexate (MTX) remains the most commonly used disease modifying antirheumatic drug in rheumatoid arthritis (RA) because of its cost and experience in its use, despite the availability of new treatments such as leflunomide and the biological agents. However, a significant number of patients with RA either do not benefit from the drug or are unable to tolerate it. Pharmacogenetic approaches may help optimise treatment with MTX, and also other agents, in RA.

\section{EPIDEMIOLOGY OF RHEUMATOID ARTHRITIS}

Rheumatoid arthritis (RA), a chronic disease with substantial costs to both the individual and society, affects about $0.5-1 \%$ of the general population world wide. ${ }^{1}$ Costs include those resulting from direct medical care and those associated with work loss, pain, psychological distress, and limitations in function. Disability occurs often. About a half of the patients with RA eventually become work disabled, and mortality is increased in patients with severe, active disease. ${ }^{2}$ However, deformity, disability and death can be reduced by the use of disease modifying antirheumatic drugs (DMARDs).

\section{EFFICACY OF MTX IN RA}

Among the several DMARDs available for the treatment of RA, methotrexate (MTX) is currently the most widely used. Gubner and Ginsburg first reported in 1951 that aminopterin (MTX) was successful in suppressing synovitis in six patients with RA. ${ }^{3}$ Since then, many studies have shown its beneficial effects in RA. Evidence for the efficacy of MTX in RA is primarily derived from four well designed randomised controlled trials performed in the mid-1980s. ${ }^{4-7}$ A multitude of subsequent studies have firmly established its efficacy in RA, with a sustained response seen in over $40 \%$ of patients. ${ }^{8}$ It has also been shown that patients with RA continue receiving MTX significantly longer than they continue with other DMARDs, with $60-70 \%$ of patients continuing to receive MTX for as long as 5-7.5 years. ${ }^{8}$

Over the past few years, several new agents for the treatment of RA have been introduced, including leflunomide and biological agents such as etanercept and infliximab. Recent evidence suggests that certain biological agents are effective in slowing the radiographic progression of disease when used alone or in combination with MTX. ${ }^{10}$ However, the high cost of some of these agents, especially the biological agents, and lack of long term safety and efficacy data preclude their use as the DMARDs of initial choice. ${ }^{11}$ Hence, MTX continues to be used as the first line DMARD in RA. ${ }^{12}$

Often in clinical practice, MTX is used as the initial DMARD until the patient is deemed a nonresponder or a partial responder, at which time another DMARD is added or substituted. ${ }^{11}$ Thus, although several agents are available for the treatment of RA, the choice of initial DMARD (which is often MTX) remains empirical.

\section{PREDICTORS OF RESPONSE TO MTX IN RA}

Despite the well accepted efficacy of MTX, response to the drug in patients with RA is not universal. Response to MTX in patients with RA based on the American College of Rheumatology 20 response rates varies from $46 \%$ to $65 \% .^{913}$ Serum levels of MTX have been considered of little value in determining drug efficacy, as the drug is eliminated from the serum within 24 hours of administration and the drug is given weekly for treatment in RA. ${ }^{14}$ By contrast, circulating intracellular levels of MTX polyglutamates in erythrocytes and polymorphonuclear cells have been shown to correlate with clinical efficacy in patients with RA, but require a difficult assay system that prohibits its availability in most clinical facilities. ${ }^{15}$

Several other factors have been studied to help predict response to treatment. Disease duration has a strong effect on the likelihood of patients responding to several DMARDs, including MTX. ${ }^{16}$ Patients with disease duration of one year or less have the best response to treatment. ${ }^{16}$ Female sex, prior DMARD use, disease functional class, and disease activity also affect patient response to treatment. ${ }^{16}$ Cytokine expression by $\mathrm{T}$ cells has

\section{Abbreviations: AICAR T'ase,}

5-aminoimidazole-4-carboxamide ribonucleotide transformylase; ALL, acute lymphoblastic leukaemia; $\mathrm{Cl}$, confidence interval; DHFR, dihydrofolate reductase; DMARD, disease modifying antirheumatic drug; FPGS folylpolyglutamate synthase; GAR T'ase, glycinamide ribonucleotide transformylase; GI, gastrointestinal; MTHFR, methylenetetrahydrofolate reductase; MTX, methotrexate; $P C R$, polymerase chain reaction; RA, rheumatoid arthritis; $\mathrm{RR}$, relative risk; SAH, S-adenosylhomocysteine; SAM, S-adenosylmethionine; THF, tetrahydrofolate; TYMS, thymidylate synthase 
been correlated with response to treatment with MTX in RA. One study showed that the response to treatment with MTX correlated with a decrease in the percentage of tumour necrosis factor $\alpha$ producing T cells and an increase in the percentage of interleukin 10 producing $\mathrm{T}$ cells. ${ }^{17}$ Serum matrix metalloproteinase-3 levels parallel serum interleukin 6 and C reactive protein levels and may correlate with response to treatment with MTX in RA. ${ }^{18}$ Enhanced tissue inhibitor of metalloproteinase- 1 production by peripheral blood mononuclear cells has also been shown to be associated with the clinical efficacy of MTX. ${ }^{19}$ Serum levels of chemokines such as RANTES (regulated upon activation, normal T cell expressed and secreted) and GRO- $\alpha$ may predict the effect of MTX on radiographic erosions. ${ }^{20}$ However, the lack of availability of sophisticated cytokine and enzyme assays in most clinical settings, in addition to the expense of running them, has prevented their use in clinical practice. Also, although such assays correlate with response to treatment, they do not predict response to treatment with MTX.

\section{MTX RESISTANCE: LESSONS FROM CANCER PUBLICATIONS}

Critical determinants of MTX resistance have been identified in lymphoblasts from children with acute lymphoblastic leukaemia (ALL). These include MTX membrane transport, dihydrofolate reductase (DHFR) levels, and MTX polyglutamation. $^{21}$ Multidrug resistance, characterised by overexpression of P-glycoprotein, a pump molecule that decreases intracellular drug concentrations by increasing drug efflux from cells, has been shown to be one of the mechanisms of MTX resistance. Transfection of multidrug resistance proteins in human ovarian carcinoma cells caused a two- to threefold lower accumulation of MTX with subsequent reduced formation of long chain polyglutamate forms of MTX and MTX resistance. ${ }^{22}$

Variants of human DHFR with substitutions at Leu22 and Phe31 causing decreased binding to MTX have been constructed. ${ }^{23}$ Such variants when transfected into Chinese hamster ovary cells or mouse marrow progenitor cells confer resistance to high levels of MTX. ${ }^{24} \mathrm{~B}$-lineage lymphoblasts in children with ALL have twofold lower levels of DHFR mRNA compared with T-lineage lymphoblasts. ${ }^{25}$ This has been postulated as one of the potential mechanisms contributing to the worse prognosis of T-lineage ALL when treated with MTX (compared with B-lineage ALL). Also, resistance to MTX in human leukaemia cell lines and in patients with acute non-lymphocytic leukaemia is associated with a marked decrease in the intracellular level of MTX polyglutamates. ${ }^{26}$ Such decreased polyglutamation is secondary to decreased activity of the enzyme folylpolyglutamate synthase (FPGS), one of the two enzymes important for the formation of intracellular MTX polyglutamates. ${ }^{26}$ Thus, both the DHFR enzyme and polyglutamation have critical roles in influencing resistance to MTX.

In contrast with the oncology literature, limited evidence exists about MTX resistance in RA. One study showed expression of P-glycoprotein in the peripheral blood mononuclear cells of patients with RA. P-glycoprotein levels were higher in 16 patients with RA refractory to treatment than in eight patients who responded to treatment with MTX, either as monotherapy or in combination with other DMARDs. ${ }^{27}$

Hence, several factors have been studied in an attempt to predict response to MTX in patients with RA. These have included clinical correlates such as disease duration and functional class, cytokine levels, and circulating intracellular levels of MTX. Although variations in the activities of several enzymes (such as P-glycoprotein, DHFR, FPGS) involved in the metabolic pathway of MTX have been shown to be important in determining the response/resistance to MTX, these have not yet been studied systematically.

\section{TOXICITY OF MTX IN RA}

Another major factor limiting MTX use is its toxicity. ${ }^{28}$ Studies with observation periods of 60 months or longer show that about $10-30 \%$ of patients with RA discontinue MTX because of toxicity. ${ }^{28}$ Several toxicities are associated with the use of MTX, including nodulosis ( $8 \%),{ }^{29}$ hypersensitivity pneumonitis $(2-5 \%))^{30}$ central nervous system toxicity $(1-35 \%),{ }^{31}$ post-dosing reactions ( $10 \%),{ }^{32}$ gastrointestinal (GI) symptoms such as nausea, vomiting, abdominal pain, and diarrhoea $(60 \%),{ }^{334}$ hepatitis with raised transaminases $(20-58 \%),{ }^{35}$ haematological abnormalities $(1-2 \%),{ }^{36}$ rash $(1-2 \%),{ }^{13}$ alopecia $(5 \%),{ }^{13}$ and osteopathy (rare). ${ }^{37}$ Known risk factors for MTX toxicity include advanced age, ${ }^{33}$ diminished renal function, ${ }^{38}$ and concurrently administered drugs. ${ }^{39}$ Because both the amount and duration of exposure to MTX have been shown to correlate with toxicity, ${ }^{40}$ it has been suggested that serum levels of MTX help predict certain types of toxicity such as gastrointestinal toxicity and myelosuppression. ${ }^{41}$ However, as MTX disappears from the serum within 24 hours of administration, serum levels are not accurate enough to predict toxicity. Hence, guidelines have been established for monitoring MTX toxicity, particularly for hepatotoxicity, that do not involve measuring serum levels. Such guidelines have been defined using evidence of end organ damage already present, such as monitoring raised transaminases for liver damage. ${ }^{42}$ Although the drug itself is relatively inexpensive, it has been shown that MTX has the highest monitoring costs among the commonly used DMARDs. ${ }^{43}$ This is particularly relevant currently, as MTX is being used increasingly in combination with other hepatotoxic agents such as leflunomide, making frequent monitoring necessary. ${ }^{44}$

\section{"Use of MTX is limited by its variable efficacy and toxicity"}

Most of the toxicity associated with MTX is thought to be linked to drug effects on folate metabolism. MTX associated GI, myelosuppressive and possibly, hepatic toxicities are thought to be directly related to its folate antagonism in these tissues, which have a high cell turnover and a relatively high requirement for purines, thymidine, and methionine. ${ }^{45} \mathrm{He}$ patic accumulation of MTX-polyglutamates has been demonstrated in liver biopsy specimens from patients with RA, accompanied by hepatic folate deficiency, suggesting that MTX-polyglutamates may cause hepatotoxicity by folate depletion. ${ }^{46}$ Folic acid supplementation at $1 \mathrm{mg} /$ day reduces such toxicity significantly. ${ }^{47}$ Other mechanisms thought to be important in mediating toxicity include inhibition of $(a)$ purine metabolism; $(b)$ adenosine deaminase with accumulation of adenosine and deoxyadenosine; (c) polyamine synthesis; and $(d)$ homocysteine metabolism. ${ }^{45}$

\section{PHARMACOGENETICS AND ITS APPLICATION TO MTX METABOLISM}

Thus the major factors limiting the use of MTX in patients with RA are its variability in efficacy and toxicity. ${ }^{82}$ At the present time, there are no reliable tests or assays that can predict the toxicity or efficacy of MTX. Nevertheless, there is potential to further improve the efficacy and decrease the toxicity from the drug through a better understanding of its pharmacology. This understanding can be gained by using the principles of pharmacogenetics to study genetic differences (polymorphisms) in the enzymes involved in the metabolic pathways of MTX.

The field of pharmacogenetics focuses largely on genetic polymorphisms in drug metabolising enzymes and the translation of inherited differences into drug effects. ${ }^{48}$ Genes are considered functionally "polymorphic" when allelic variants exist stably in the population, one or more of which alters the 
activity of the encoded protein in relation to the wild-type sequence. The genetic polymorphism may be associated with reduced activity of the encoded protein. Although the study of pharmacogenetics focuses largely on polymorphisms in drug metabolising enzymes, polymorphisms in drug transporters (such as P-glycoprotein) and drug targets (such as receptors) have also been studied. Such pharmacogenetic studies may soon make it feasible more precisely to select drugs and doses that are optimal for individual patients. In this regard, automated system based "gene chips" may become available soon, whereby an individual person's polymorphic genotype involved in the pathogenesis of their disease, in the metabolism and disposition of drugs, and in the targets of drug treatment can be determined. Such "gene chips" may become the blueprints for individualising drug treatment in the future. ${ }^{49}$

\section{"'Gene chips' may be used to individualise drug treatment"}

Until recently, clinically important genetic polymorphisms in drug metabolism were typically discovered on the basis of familial occurrence or extreme phenotypic differences among individual subjects in the population. Recent advances in the field of genetics, specifically pharmacogenetics, have changed this. With molecular sequencing technology, genetic polymorphisms such as single nucleotide polymorphisms can now be detected. When translated to clinical studies, such technology may permit the elucidation of polymorphisms in drug metabolising enzymes that may have clinically important consequences, such as interindividual variability in drug response or drug toxicity. ${ }^{49}$ Such polymorphisms may be readily detectable to help assess drug response or toxicity even when traditional approaches are not fruitful.

MTX was developed to be a highly selective competitive inhibitor of the enzyme DHFR. ${ }^{44}$ MTX enters cells through an active transport mechanism. Once inside the cell, it is converted into a polyglutamate form by the enzyme FPGS (fig 1). This process can be reversed by the enzyme folylpolyglutamate hydrolase. The polyglutamate form of MTX which can have up to four glutamic acid moieties (a) retains MTX within the cell for long periods $s^{50} ;(b)$ inhibits DHFR which mediates the conversion of dihydrofolate to tetrahydrofolate (THF), the precursor of biologically active folate cofactors such as 5-methyl- THF, important for the conversion of homocysteine to methionine and in the synthesis of polyamines ${ }^{45} ;(c)$ increases the potency for inhibiting thymidylate synthase (TYMS), which converts deoxyuridylate to deoxythymidylate in the de novo pyrimidine biosynthetic pathway ${ }^{51}$; and $(d)$ increases the potency for directly inhibiting enzymes, such as glycinamide ribonucleotide transformylase (GAR T'ase) and 5-aminoimidazole-4-carboxamide ribonucleotide transformylase (AICAR T'ase), ${ }^{52}$ which play a part in de novo purine biosynthesis. The ability of MTX to inhibit these enzymes increases as the number of glutamate moieties increases. The pentaglutamate form of MTX is about 2500 times more potent in inhibiting AICAR T'ase, 250 times more potent in inhibiting TYMS, and 32 times more potent in inhibiting GAR T'ase than the native monoglutamate form. ${ }^{44}$

MTX, by affecting the intracellular folate pool, influences the activity of the enzyme methylenetetrahydrofolate reductase (MTHFR), one of the enzymes in the folate pathway (fig 1). MTHFR is important in the generation of 5-methyl-THF, which is the methyl donor for the conversion of homocysteine to methionine. Methionine is used for the synthesis of $S$-adenosylmethionine (SAM), which is converted to $S$-adenosylhomocysteine (SAH) and homocysteine. ${ }^{53}$ SAM is the methyl donor for over a 100 different transmethylation reactions, including methylation of DNA and proteins, phospholipid synthesis, and neurotransmitter synthesis. ${ }^{54}$
Recently, heterozygous and homozygous Mthfr knockout mice have been developed, which have raised plasma homocysteine and disrupted SAM and SAH levels that are associated with DNA hypomethylation in several tissues. Such mice have reduced survival, delayed development, cerebellar abnormalities and abnormal lipid deposition in the proximal aorta. ${ }^{55}$ Thus, the MTHFR enzyme impacts several crucial cellular processes and its deficiency can have widespread consequences.

More than a dozen polymorphisms have been described in the MTHFR gene. ${ }^{56}$ Of these, the C677T and A1298C polymorphisms have been associated with altered phenotypes and adverse drug events. The C677T polymorphism, first described in the mid-1990s, results in an alanine to valine substitution in the codon at nucleotide 677 of the MTHFR gene. ${ }^{57}$ It leads to a thermolabile variant of MTHFR with decreased enzyme activity, and subsequent increased plasma homocysteine levels. ${ }^{58}$ The homozygous C677T variant, with about 30\% of wild-type activity, is present in about $8-10 \%$ of the general population. Heterozygotes have about $60 \%$ activity and form approximately $40 \%$ of the population. The C677T polymorphism has been shown to be associated with decreased risk for ALL and colorectal neoplasia, and increased risk for neural tube defects and cardiovascular disease. ${ }^{59-63}$ It has also been shown to influence the clinical effects of drugs such as anticonvulsants, levodopa, oestrogen, and cholestyramine. ${ }^{64-67}$

In 1998, another polymorphism in the MTHFR gene, A1298C, causing a glutamine to alanine substitution in the codon at nucleotide 1298, was described. ${ }^{68} 69$ Both the homozygous and the heterozygous polymorphisms lead to reduced activity of the MTHFR enzyme, although not to a thermolabile variant. The homozygous genotype with $\sim 60 \%$ of enzyme activity in lymphocytes has been found in $~ 10 \%$ of the Canadian population (prevalence world wide unknown) ${ }^{69}$ The Al298C polymorphism, by itself, does not result in increased plasma homocysteine levels. However, subjects heterozygous for both the C677T and A1298C polymorphisms have significantly decreased activity of the MTHFR enzyme and raised plasma homocysteine levels comparable with subjects homozygous for the C677T polymorphism. ${ }^{68}$ An increased frequency of the Al298C polymorphism has been seen in children with neural tube defects. ${ }^{68}$

The effect of the C677T polymorphism on the toxicity of MTX in patients undergoing bone marrow transplantation was studied recently. Two hundred and twenty patients with chronic myelogenous leukaemia who underwent marrow allografts and received MTX for prevention of graft versus host disease were assessed for MTX toxicity prospectively. Toxicities assessed included oral mucositis, speed of engraftment (platelet and granulocyte counts), and hepatotoxicity (measurement of bilirubin). All patients were genotyped for the C677T polymorphism. Forty two per cent of the patients were wild type, $42 \%$ heterozygous, and 16\% homozygous. There was a higher incidence of oral mucositis in patients with the homozygous and heterozygous genotypes, reaching statistical significance with the homozygous genotype. Recovery of platelet counts was slower among patients with the polymorphism than among patients with the wild type. There was no effect of the genotype on recovery of granulocyte counts or bilirubin levels. This study demonstrated a relation between the C677T polymorphism and MTX toxicity, with patients with the homozygous genotype experiencing higher toxicity. ${ }^{70}$

Research that examines the influence of pharmacogenetics on both the efficacy and toxicity of MTX in RA is just beginning to appear. Plasma homocysteine levels were measured prospectively in 105 patients with RA, 35 of whom were treated with MTX, 34 with sulfasalazine, and 36 with a combination of MTX and sulfasalazine. All patients were genotyped for the C677T polymorphism in the MTHFR gene by polymerase chain reaction (PCR) and restriction enzyme analysis. The two treatment groups receiving MTX showed a 


\begin{tabular}{|ll|}
\hline & \\
DHF & Dihydrofolate \\
DHFR & Dihydrofolate reductase \\
FPGS & Folylpolyglutamate synthase \\
FPGH & Folylpolyglutamate hydrolase \\
MTHFR & Methylenetetrahydrofolate reductase \\
MTX & Methotrexate \\
MTX-PG & Methotrexate polyglutamate \\
THF & Tetrahydrofolate \\
$5-\mathrm{CH}_{3}-\mathrm{THF}$ & Methyl-THF \\
$5,10-\mathrm{CH}_{2}-\mathrm{THF}$ & Methylene-THF \\
TYMS & Thymidylate synthase \\
\hline
\end{tabular}

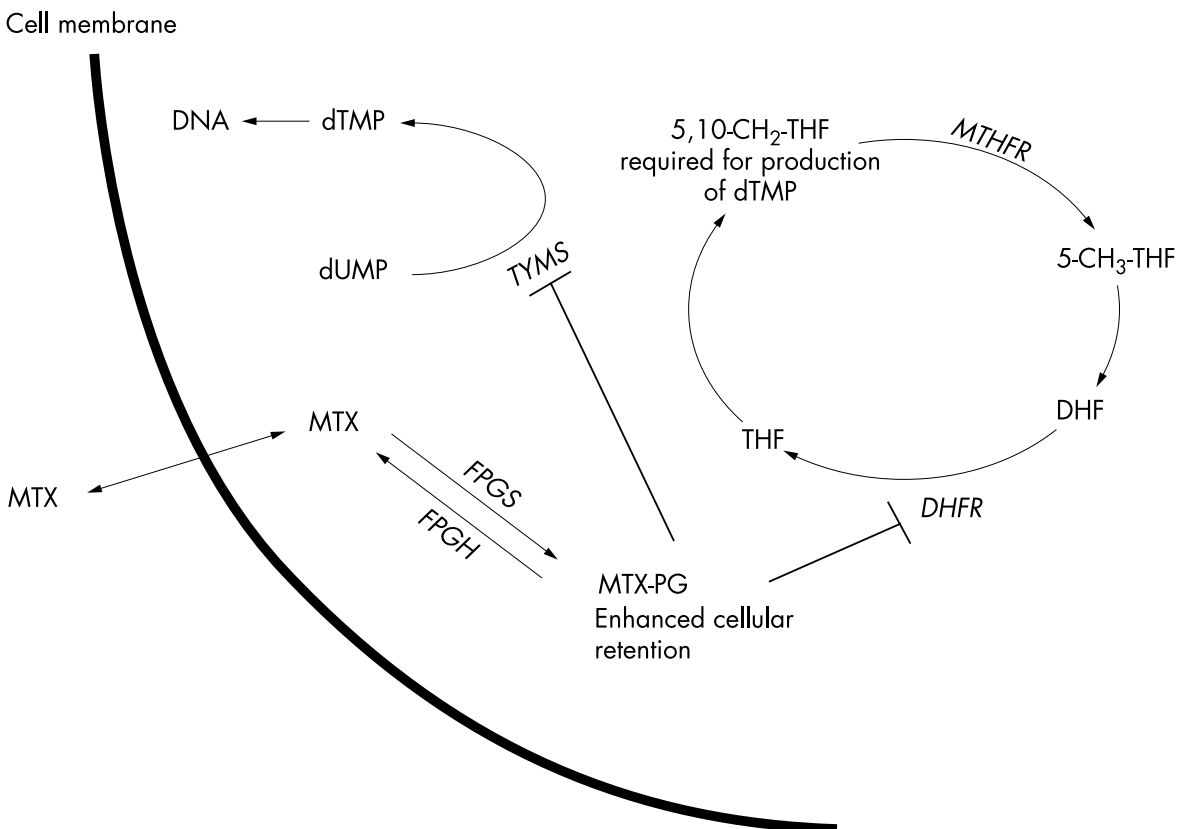

Figure 1 Putative targets for MTX pharmacogenetic analysis (shown in italics).

persistent, greater increase in plasma homocysteine than the group receiving sulfasalazine alone, with the patients receiving a combination of MTX and sulfasalazine showing the greatest increase. The MTHFR genotype influenced the rise in homocysteine. Patients with the heterozygous mutation had higher plasma homocysteine after one year than patients without the mutation. Patients homozygous for the mutation had a high plasma homocysteine level at baseline which did not change significantly, possibly because of a ceiling effect. A statistically significant higher rise in plasma homocysteine (an increase of $17 \%, \mathrm{p}<0.05$ ) was found in patients experiencing a GI adverse event (nausea, abdominal discomfort/pain) than in patients without an adverse event. Also, patients treated with the combination of MTX and sulfasalazine had the highest homocysteine levels and the highest incidence of GI side effects. There was no direct relation between the occurrence of adverse events and the MTHFR genotype. The authors concluded that patients with RA receiving MTX have increased plasma homocysteine levels, which may be further enhanced by the C677T polymorphism in the MTHFR gene. Plasma homocysteine may be important in mediating the gastrointestinal toxicity from MTX. ${ }^{71}$

In another study, 236 patients with RA receiving MTX were assessed prospectively for toxicity and disease activity every three and six weeks, respectively. All patients were genotyped for the C677T MTHFR polymorphism using genomic DNA by PCR and restriction enzyme analysis. Nineteen patients (8\%) had the homozygous polymorphism, 95 patients (40\%) had the heterozygous polymorphism, and 122 patients (52\%) did not have the polymorphism. The presence of the C677T poly- morphism (homozygous or heterozygous) was associated with an increased risk (relative risk (RR) 2.01; 95\% confidence interval (95\% CI) 1.09 to 3.70 ) of MTX discontinuation because of adverse events such as GI symptoms, hair loss, and hepatotoxicity. The polymorphism led to MTX discontinuation mainly due to an increased risk of raised liver enzymes, specifically alanine aminotransferase (RR 2.38; 95\% CI 1.06 to 5.34). The predictive power of the genotype was independent of folate supplementation. No relation was seen between the polymorphism and the efficacy of MTX in this study. The authors postulated that an increase of transaminases during MTX treatment in RA is mediated by its effects on homocysteine metabolism. Such effects may be more pronounced in patients with the C677T polymorphism receiving MTX.72

In a retrospective analysis, 106 patients with RA were genotyped for the C677T and Al298C polymorphisms in the MTHFR gene using the PCR-restriction fragment length polymorphism method. All patients were receiving MTX at the time of enrolment or had discontinued MTX in the past because of adverse events. The efficacy and toxicity of MTX were assessed in patients and correlated with the presence or absence of the C677T and Al298C polymorphisms. Patients homozygous or heterozygous for the Al298C polymorphism were receiving lower doses of MTX than patients without the polymorphism ( $\mathrm{p}<0.05$, RR 2.18 ; $95 \%$ CI 1.17 to 4.06$)$. The presence of the polymorphism was associated with improvements in $\mathrm{C}$ reactive protein levels and erythrocyte sedimentation rates $(\mathrm{p}<0.05)$, but not in tender or swollen joint counts. 
No such associations were found with the C677T polymorphism. However, overall MTX toxicity, such as increase in transaminases, stomatitis, nausea, vomiting, hair loss, fatigue, and rash, was more common in patients homozygous or heterozygous for the C677T polymorphism than in patients without the polymorphism $(\mathrm{p}<0.05$, RR $1.25 ; 95 \%$ CI 1.05 to 1.49). There was no effect of the Al298C polymorphism on toxicity. Thus, the C677T polymorphism made patients with RA more sensitive to MTX toxicity, whereas the Al298C polymorphism made them more responsive to treatment. ${ }^{73}$

Thus, so far, only genetic polymorphisms in the MTHFR enzyme, one of the enzymes in the metabolic pathway of MTX, have been studied. These studies have demonstrated the predictive power of the MTHFR genotype in determining MTX toxicity, with one study showing that two different polymorphisms in the MTHFR gene are related to two different phenotypes-that is, MTX efficacy and toxicity in RA. Single nucleotide polymorphisms in other enzymes involved in the metabolic pathway of MTX may be better predictors of MTX efficacy and toxicity. In vitro studies have already established the important roles of such enzymes, including DHFR (which is the substrate for MTX and may be the rate limiting enzyme in the folate pathway) and FPGS (critical for MTX polyglutamation), in mediating MTX resistance. Also, certain polymorphisms may translate into potent functional differences in enzyme activity while others may not. Hence, further studies are needed to study polymorphisms in other enzymes in the MTX pathway and their correlations with drug efficacy and toxicity in RA.

\section{SUMMARY}

Despite the availability of several new agents for the treatment of RA, MTX remains the mainstay because of both cost and experience with its use. However, there is considerable variation in the response to MTX, with toxicity limiting treatment in some patients. At present, there are no standardised tests to predict the drug's efficacy or toxicity in RA. It may be possible to develop such tests in the future based on the principles of pharmacogenetics. There is some initial evidence supporting the influence of pharmacogenetics on the efficacy and toxicity of MTX in RA. Potentially, the principles of pharmacogenetics can be applied to optimise drug treatment, not only with MTX, but also with other drugs, including the newer agents such as leflunomide and the biological therapies. Such applications will have tremendous impact, given our current inability to predict which patients with RA will respond to these drugs or develop toxicity and the high costs of some of these agents.

\section{ACKNOWLEDGEMENT}

Work in the Yokoyama and McLeod laboratories is supported by grants from the National Institutes of Health, in particular U01 GM63340. Dr Yokoyama is an investigator of the Howard Hughes Medical Institute.

\section{Authors' affiliations}

P Ranganathan, Division of Rheumatology and Department of Medicine, Washington University School of Medicine, St Louis, Missouri 63110 , USA

S Eisen, Division of Rheumatology and Department of Medicine, Washington University School of Medicine; and St Louis VA Medical Center, St Louis, Missouri 63106, USA

W M Yokoyama, Division of Rheumatology, Department of Medicine, and Howard Hughes Medical Institute, Washington University School of Medicine

H L McLeod, Departments of Medicine, Molecular Biology and

Pharmacology, and Genetics, Washington University School of Medicine

\section{REFERENCES}

1 Pugner KM, Scott DI, Holmes JW, Hieke K. The costs of rheumatoid arthritis: an international long-term view. Semin Arthritis Rheum 2000;29:305-20.
2 Pincus T, Callahan LF, Sale WG, Brooks AL, Payne LE, Vaughn WK. Severe functional declines, work disability, and increased mortality in seventy-five rheumatoid arthritis patients studied over nine years. Arthritis Rheum 1984;27:864-72.

3 Gubner R AS, Ginsburg V. Therapeutic suppression of tissue reactivity. Effects of aminopterin in rheumatoid arthritis and psoriasis. Am J Med Sci 1951;221:176-82

4 Williams HJ, Willkens RF, Samuelson CO Jr, Alarcon GS, Guttadauria $M$, Yarboro $C$, et al. Comparison of low-dose oral pulse methotrexate and placebo in the treatment of rheumatoid arthritis. A controlled clinical trial. Arthritis Rheum 1985:28:721-30.

5 Thompson RN, Watts C, Edelman J, Esdaile J, Russell AS. A controlled two-centre trial of parenteral methotrexate therapy for refractory rheumatoid arthritis. J Rheumatol 1984;1 1:760-3.

6 Andersen PA, West SG, O'Dell JR, Via CS, Claypool RG, Kotzin BL. Weekly pulse methotrexate in rheumatoid arthritis. Clinical and immunologic effects in a randomized, double-blind study. Ann Intern Med 1985; 103:489-96.

7 Weinblatt ME, Coblyn JS, Fox DA, Fraser PA, Holdsworth DE, Glass $\mathrm{DN}$, et al. Efficacy of low-dose methotrexate in rheumatoid arthritis. $\mathrm{N}$ Engl J Med 1985;312:818-22.

8 Kremer JM, Phelps CT. Long-term prospective study of the use of methotrexate in the treatment of rheumatoid arthritis. Update after a mean of 90 months. Arthritis Rheum 1992;35:138-45.

9 Bathon JM, Martin RW, Fleischmann RM, Tesser JR, Schiff MH, Keystone $\mathrm{EC}$, et al. A comparison of etanercept and methotrexate in patients with early rheumatoid arthritis. N Engl J Med 2000;343:1586-93.

10 Lipsky PE, van der Heijde DM, St Clair EW, Furst DE, Breedveld FC, Kalden JR, et al. Infliximab and methotrexate in the treatment of rheumatoid arthritis. Anti-Tumor Necrosis Factor Trial in Rheumatoid Arthritis with Concomitant Therapy Study Group. N Engl J Med 2000;343: 1594-602

11 Kremer JM. Rational use of new and existing disease-modifying agents in rheumatoid arthritis. Ann Intern Med 2001;134:695-706.

12 American College of Rheumatology Subcommittee on Rheumatoid Arthritis. Guidelines for the management of rheumatoid arthritis: 2002 update. Arthritis Rheum 2002;46:328-46.

13 Strand V, Cohen S, Schiff M, Weaver A, Fleischmann R, Cannon G, et al. Treatment of active rheumatoid arthritis with leflunomide compared with placebo and methotrexate. Leflunomide Rheumatoid Arthritis Investigators Group. Archiv Intern Med 1999;159:2542-50.

14 Bannwarth B, Pehourcq F, Schaeverbeke T, Dehais J. Clinical pharmacokinetics of low-dose pulse methotrexate in rheumatoid arthritis. Clin Pharmacokinet 1996;30:194-210

15 Angelis-Stoforidis P, Vajda FJ, Christophidis N. Methotrexate polyglutamate levels in circulating erythrocytes and polymorphs correlate with clinical efficacy in rheumatoid arthritis. Clin Exp Rheumatol 1999; 17:313-20.

16 Anderson JJ, Wells G, Verhoeven AC, Felson DT. Factors predicting response to treatment in rheumatoid arthritis: the importance of disease duration. Arthritis Rheum 2000:43:22-9.

17 Rudwaleit M, Yin Z, Siegert S, Grolms M, Radbruch A, Braun J, et al. Response to methotrexate in early rheumatoid arthritis is associated with a decrease of T cell derived tumour necrosis factor alpha, increase of interleukin 10, and predicted by the initial concentration of interleukin 4 Ann Rheum Dis 2000;59:31 1-14.

18 Ribbens C, Andre B, Jaspar JM, Kaye O, Kaiser M, De Groote D, et al. Matrix metalloproteinase-3 serum levels are correlated with disease activity and predict clinical response in rheumatoid arthritis. J Rheumatol 2000;27:888-93.

19 Seitz M, Dayer JM. Enhanced production of tissue inhibitor of metalloproteinases by peripheral blood mononuclear cells of rheumatoid arthritis patients responding to methotrexate treatment. Rheumatology (Oxford) 2000;39:637-45.

20 Boiardi L, Macchioni P, Meliconi R, Pulsatelli L, Facchini A, Salvarani C. Relationship between serum RANTES levels and radiological progression in rheumatoid arthritis patients treated with methotrexate. Clin Exp Rheumatol 1999;17:419-25.

21 Matherly LH, Taub JW. Methotrexate pharmacology and resistance in childhood acute lymphoblastic leukemia. Leukemia Lymphoma 1996;21:359-68.

22 Hooijberg JH, Broxterman HJ, Kool M, Assaraf YG, Peters GJ, Noordhuis $\mathrm{P}$, et al. Antifolate resistance mediated by the multidrug resistance proteins MRP1 and MRP2. Cancer Res 1999;59:2532-5.

23 Ercikan-Abali EA, Mineishi S, Tong Y, Nakahara S, Waltham MC Baneriee $D$, et al. Active site-directed double mutants of dihydrofolate reductase. Cancer Res 1996;56:4142-5.

24 Baneriee D, Schweitzer BI, Volkenandt M, Li MX, Waltham M, Mineishi $\mathrm{S}$, et al. Transfection with a cDNA encoding a Ser31 or Ser34 mutant human dihydrofolate reductase into Chinese hamster ovary and mouse marrow progenitor cells confers methotrexate resistance. Gene 1994; 139:269-74

25 Galpin AJ, Schuetz JD, Masson E, Yanishevski Y, Synold TW, Barredo $J C$, et al. Differences in folylpolyglutamate synthetase and dihydrofolate reductase expression in human B-lineage versus T-lineage leukemic lymphoblasts: mechanisms for lineage differences in methotrexate polyglutamylation and cytotoxicity. Mol Pharmacol 1997;52:155-63.

26 Barnes MJ, Estlin EJ, Taylor GA, Aherne GW, Hardcastle A, McGuire JJ, et al. Impact of polyglutamation on sensitivity to raltitrexed and methotrexate in relation to drug-induced inhibition of de novo thymidylate and purine biosynthesis in CCRF-CEM cell lines. Clin Cancer Res 1999;5:2548-58. 
27 Llorente L, Richaud-Patin Y, Diaz-Borion A, Alvarado de la Barrera C, Jakez-Ocampo J, de la Fuente $\mathrm{H}$, et al. Multidrug resistance-1 (MDR-1) in rheumatic autoimmune disorders. Part I: Increased P-glycoprotein activity in lymphocytes from rheumatoid arthritis patients might influence disease outcome. Joint Bone Spine 2000:67:30-9.

28 Alarcon GS, Tracy IC, Blackburn WD Jr. Methotrexate in rheumatoid arthritis. Toxic effects as the major factor in limiting long-term treatment. Arthritis Rheum 1989;32:671-6.

29 Kerstens PJ, Boerbooms AM, Jeurissen ME, Fast JH, Assmann KJ, van de Putte LB. Accelerated nodulosis during low dose methotrexate therapy for rheumatoid arthritis. An analysis of ten cases [see comments]. J Rheumatol 1992;19:867-71.

30 Carson CW, Cannon GW, Egger M, Ward JR, Clegg DO. Pulmonary disease during the treatment of rheumatoid arthritis with low dose pulse methotrexate. Semin Arthritis Rheum 1987; 16:186-95.

31 Wernick R, Smith DL. Central nervous system toxicity associated with weekly low-dose methotrexate treatment. Arthritis Rheum 1989;32:770-5

32 Halla JT, Hardin JG. Underrecognized postdosing reactions to methotrexate in patients with rheumatoid arthritis. J Rheumatol 1994;21:1224-6.

33 Buchbinder R, Hall S, Sambrook PN, Champion GD, Harkness A, Lewis $D$, et al. Methotrexate therapy in rheumatoid arthritis: a life table review of 587 patients treated in community practice. J Rheumatol 1993;20:639-44.

34 McKendry RJ, Dale P. Adverse effects of low dose methotrexate therapy in rheumatoid arthritis. J Rheumatol 1993;20:1850-6.

35 West SG. Methotrexate hepatotoxicity. Rheum Dis Clin North Am 1997;23:883-915

36 Gutierrez-Urena S, Molina JF, Garcia CO, Cuellar ML, Espinoza LR. Pancytopenia secondary to methotrexate therapy in rheumatoid arthritis [see comments]. Arthritis Rheum 1996;39:272-6.

37 Zonneveld IM, Bakker WK, Dijkstra PF, Bos JD, van Soesbergen RM, Dinant HJ. Methotrexate osteopathy in long-term, low-dose methotrexate treatment for psoriasis and rheumatoid arthritis. Archiv Dermatol 1996;132:184-7

38 Henderson ES, Adamson RH, Oliverio VT. The metabolic fate of tritiated methotrexate. II. Absorption and excretion in man. Cancer Res 1965;25:1018-24.

39 Groenendal H, Rampen FH. Methotrexate and trimethoprim-sulphamethoxazole-a potentially hazardous combination [see comments]. Clin Exp Dermatol 1990;15:358-60.

40 Bleyer WA. The clinical pharmacology of methotrexate: new applications of an old drug. Cancer 1978:41:36-51.

41 Wallace CA, Sherry DD. A practical approach to avoidance of methotrexate toxicity [editorial]. J Rheumatol 1995;22:1009-12.

42 Kremer JM, Alarcon GS, Lightfoot RW Jr, Willkens RF, Furst DE, Williams HJ, et al. Methotrexate for rheumatoid arthritis. Suggested guidelines for monitoring liver toxicity. American College of Rheumatology [see comments]. Arthritis Rheum 1994;37:316-28.

43 Prashker MJ, Meenan RF. The total costs of drug therapy for rheumatoid arthritis. A model based on costs of drug, monitoring, and toxicity [see comments]. Arthritis Rheum 1995,38:318-25

44 Kremer JM. Methotrexate and leflunomide: biochemical basis for combination therapy in the treatment of rheumatoid arthritis. Semin Arthritis Rheum 1999;29:14-26.

45 van Ede AE, Laan RF, Blom HJ, De Abreu RA, van de Putte LB. Methotrexate in rheumatoid arthritis: an update with focus on mechanisms involved in toxicity. Semin Arthritis Rheum 1998;27:277-92.

46 Kremer JM, Galivan J, Streckfuss A, Kamen B. Methotrexate metabolism analysis in blood and liver of rheumatoid arthritis patients. Association with hepatic folate deficiency and formation of polyglutamates. Arthritis Rheum 1986;29:832-5.

47 Morgan SL, Baggott JE, Vaughn WH, Young PK, Austin JV, Krumdieck $\mathrm{CL}$, et al. The effect of folic acid supplementation on the toxicity of low-dose methotrexate in patients with rheumatoid arthritis [see comments]. Arthritis Rheum 1990;33:9-18.

48 McLeod HL, EvansWE. Pharmacogenomics: unlocking the human genome for better therapy. Annu Rev Pharmacol Toxicol 2001;201:101-21

49 Evans WE, Relling MV. Pharmacogenomics: translating functional genomics into rational therapeutics. Science 1999;286:487-91.

50 Galivan J. Evidence for the cytotoxic activity of polyglutamate derivatives of methotrexate. Mol Pharmacol 1980;17:105-10.

51 Szeto DW, Cheng YC, Rosowsky A, Yu CS, Modest EJ, Piper JR, et al. Human thymidylate synthetase. III. Effects of methotrexate and folate analogs. Biochem Pharmacol 1979;28:2633-7.
52 Chabner BA, Allegra CJ, Curt GA, Clendeninn NJ, Baram J, Koizumi S, et al. Polyglutamation of methotrexate. Is methotrexate a prodrug? J Clin nvest 1985;76:907-12

53 Ueland PM. Pharmacological and biochemical aspects of S-adenosylhomocysteine and S-adenosylhomocysteine hydrolase. Pharmacol Rev 1982;34:223-53.

54 Chiang PK, Gordon RK, Tal J, Zeng GC, Doctor BP, Pardhasaradhi K, et al. S-Adenosylmethionine and methylation. FASEB J'1996; 10:471-80.

55 Chen Z, Karaplis AC, Ackerman SL, Pogribny IP, Melnyk S, Lussier-Cacan S, et al. Mice deficient in methylenetetrahydrofolate reductase exhibit hyperhomocysteinemia and decreased methylation capacity, with neuropathology and aortic lipid deposition. Hum Mol Genet 2001; 10:433-43.

56 Rozen R. Molecular genetics of methylenetetrahydrofolate reductase deficiency. J Inherit Metab Dis 1996; 19:589-94.

57 Frosst P, Blom HJ, Milos R, Goyette P, Sheppard CA, Matthews RG, et al. A candidate genetic risk factor for vascular disease: a common mutation in methylenetetrahydrofolate reductase. Nat Genet 1995;10:111-13.

58 Kang SS, Zhou J, Wong PW, Kowalisyn J, Strokosch G. Intermediate homocysteinemia: a thermolabile variant of methylenetetrahydrofolate reductase. Am J Hum Genet 1988;43:414-21.

59 Skibola CF, Smith MT, Kane E, Roman E, Rollinson S, Cartwright RA, et al. Polymorphisms in the methylenetetrahydrofolate reductase gene are associated with susceptibility to acute leukemia in adults. Proc Natl Acad Sci USA 1999;96:12810-15.

60 Chen J, Giovannucci E, Kelsey K, Rimm EB, Stampfer M, Colditz GA, et al. A methylenetetrahydrofolate reductase polymorphism and the risk of colorectal cancer. Cancer Res 1996:56:4862-4

61 Ulrich CM, Kampman E, Bigler J, Schwartz SM, Chen C, Bostick R, et al. Colorectal adenomas and the C677T MTHFR polymorphism: evidence for gene-environment interaction? Cancer Epidemiol Biomarkers Prev 1999;8:659-68.

62 Ou CY, Stevenson RE, Brown VK, Schwartz CE, Allen WP, Khoury M, et al. 5,10 Methylenetetrahydrofolate reductase genetic polymorphism as a risk factor for neural tube defects. Am J Med Genet 1996:63:610-14.

63 Kluijtmans LA, Kastelein JJ, Lindemans J, Boers GH, Heil SG, Bruschke $\mathrm{AV}$, et al. Thermolabile methylenetetrahydrofolate reductase in coronary artery disease. Circulation 1997;96:2573-7.

64 Vilaseca MA, Monros E, Artuch R, Colome C, Farre C, Valls C, et al. Anti-epileptic drug treatment in children: hyperhomocysteinaemia, B-vitamins and the $677 \mathrm{C} \rightarrow$ T mutation of the methylenetetrahydrofolate reductase gene. Eur J Paediatr Neurol 2000;4:269-77

65 Yasui K, Kowa H, Nakaso K, Takeshima T, Nakashima K. Plasma homocysteine and MTHFR C677T genotype in levodopa-treated patients with PD. Neurology 2000;55:437-40.

66 Brown CA, McKinney KQ, Young KB, Norton HJ. The C677T methylenetetrahydrofolate reductase polymorphism influences the homocysteine-lowering effect of hormone replacement therapy. Mol Genet Metab 1999;67:43-8.

67 Tonstad S, Refsum H, Ose L, Ueland PM. The C677T mutation in the methylenetetrahydrofolate reductase gene predisposes to hyperhomocysteinemia in children with familial hypercholesterolemia treated with cholestyramine. J Pediatr 1998;132:365-8.

68 Gabreels F, Stevens EM, Smeitink JA, Trijbels FJ, Eskes TK, van den Heuvel LP, et al. A second common mutation in the methylenetetrahydrofolate reductase gene: an additional risk factor for neural-tube defects? Am J Hum Genet 1998;62:1044-51.

69 Winegrad S, Weisberg I. A second genetic polymorphism in methylenetetrahydrofolate reductase (MTHFR) associated with decreased enzyme activity. [see comments]. Circ Res 1998;83:60-72

70 Ulrich CM, Yasui Y, Storb R, Schubert MM, Wagner JL, Bigler J, et al. Pharmacogenetics of methotrexate: toxicity among marrow transplantation patients varies with the methylenetetrahydrofolate reductase C677T polymorphism. Blood 2001;98:231-4.

71 Haagsma CJ, Blom HJ, van Riel PL, van't Hof MA, Giesendorf BA, van Oppenraaij-Emmerzaal D, et al. Influence of sulphasalazine, methotrexate, and the combination of both on plasma homocysteine concentrations in patients with rheumatoid arthritis. Ann Rheum Dis 1999:58:79-84.

72 van Ede AE, Laan RFJM, Blom HJ, Huizinga TWJ, Haagsma CJ, Giesendorf BAJ, et al. The C677T mutation in the methylenetetrahydrofolate reductase gene: a genetic risk factor for methotrexate-related elevation of liver enzymes in rheumatoid arthritis patients. Arthritis Rheum 2001:44:2525-30.

73 Urano W, Taniguchi A, Yamanaka H, Tanaka E, Nakajima H, Matsuda $Y$, et al. Polymorphisms in the methylenetetrahydrofolate reductase gene were associated with both the efficacy and toxicity of methotrexate used for the treatment of rheumatoid arthritis, as evidenced by single locus and haplotype analyses. Pharmacogenetics 2002;12:183-90. 